\title{
THE VISION OF ANCIENT LIFE*
}

\author{
By Prof. Rhys Carpenter, \\ Bryn Mawr College
}

$I^{\mathrm{T}}$ has been the destiny of classic Greek civilization to serve as a mirror of perfection into which later ages might peer and see the good, the beautiful, the true. Within that magic glass the ordinary world has been transmuted to a stately calm, a pageant of august forms-beautiful boys, god-like youths, and serene elders, moving among white temples beneath sunlit skies. Read Goethe's "Iphigenie", consult the painters and sculptors of the late eighteenth and early nineteenth centuries, listen to John Addington Symonds and Walter Pater-not one has cherished any serious doubts of the perfection of the classical ideal. Theirs has indeed been an untroubled vision of ancient life.

But it is unnecessary to tell an audience from the disillusioned year 1940 that such a vision must be false, that this classic world has been conjured up through glasses of enchantment and that, had those glasses possessed any of the accuracy of the optician's or the laboratory worker's lenses, the ancient world would have lost its iridescence, the crystal must have revealed its flaws. It has been the modern archæologist's sad privilege to provide glasses of disenchantment and to stare through them steadily at the beauty of Greece. Long before his time, however, the political historian had discovered that all was not well with Hellenic polity, that an Egean world of unintegrated, narrowly self-conscious, democratic CityStates had consumed itself in jealousy, intrigue and hatred, and had finally succtmbed to every military dictator who chose to move against it. Still, this was only an imperfection of a special and restricted kind. Even while they deplored the feral self-destruction which lurked within Greek civilization, these same historians repeated the chant of the serenity of Greek art, the calm superiority of Greek letters, the instinctive beauty of the Greek way of living. It needed the archæologist to discover that there was no single material aspect of the classic civilization which could endure a really close scrutiny and still maintain its calm poise of assumed impeccability.

A measuring-stick and a scrupulously attentive eye can work strange havoc with the perfection of a Greek temple. Identical parts refuse to reveal identical dimensions: some are over size, some

* Substance of a paper read at the Bicentennial Conference, University of Pennsylvania, on September 16. under, others are miscut and patched; errors of computation vie with errors of execution; outright miscalculation betrays itself under a guise of last-minute improvization. The most perfect of ancient buildings, the Parthenon, sets us some surprising problems. In their general trend, most of its irregularities are deliberate. The curving steps, the leaning superstructure, the gradual increase or decrease in size of identical members as we move toward or away from the corners of the building - these are not errors or accidents, but are wisely founded in optical æsthetics, in the laws of artistic vision. But look and measure a little closer still : the curve of the steps is no longer a true curve at all, but a ragged broken line; the leaning columns and entablatures sway and stagger; the changing dimensions move fitfully and out of step. Are these still more subtle, but equally deliberate, refinements? Is this inaccuracy merely a coldly calculated blurring of the mathematically too perfect calculation? Or are they all mere human frailty, marking the natural limits of artistry and revealing the unselfconscious slipping of hand or eye or brain? There are champions of both interpretations. But the defenders of Greek perfection $\dot{a}$ l'outrance, who refuse to allow that a modern scientific instrument can detect an aberration which the ancient artist had not seen and willed, these are gradually being removed from. the ranks of the men of science, to take refuge among the mystics and archæological astrologers.

Again, the most casual spectator can perceive the marvellous technical achievement inherent in Attic pottery, the baked, glazed and painted clay which was shaped to cups, pitchers, bowls, and jars with such consummate mastery of curving outlines and balanced harmony of form. But again the more scrupulously attentive eye, resigned to the use of calipers and foot-rules, will fall foul of the same predicament as in the temples. These tiny deviations from exactness, these shifts and changes from an obvious potter's norm, do these betoken the inmost subtleties of the Greek creative brain, or do they but mark the normal limit of human attentiveness and ambition? Again there have been champions of both interpretations. The ingenious exponents of dynamic symmetry have stripped the potter's wheel and kiln-even his clay and water and air-of their casual variability; but in order to rescue their ideal of 
Greek infallibility, they have had to take refuge in a special geometry which is not so much abstruse as meaningless. These are quarrels of our profession dating from our own times; but even if some of their differences have not been finally composed to the satisfaction of all contestants, the general trend of the results is clear. Beneath the merciless scrutiny of modern scientific instru= ments of precision, the utter perfectness of Greek artistry has proved illusory.

In statuary, where the dogma of Greek ideal perfection has been perhaps most obstinately enshrined, the outcome is the same. The Hermes of Praxiteles was so miscut by its unknown maker that a considerable portion of the back had to be rehewn after the statue was all but finished. In the pediments of the Parthenon one of the figures was so tall that its head struck the overhanging marble cornice and a hollow bed had to be sunk in the pediment floor before the piece could be fitted into its proper position. Another pair of statues jostled each other for room to such an extent that at the last moment a workman had to chip away from the finished sculpture an obstructing projection. High in the Arcadian mountains, when the twenty-three slabs of a carved frieze to adorn the interior of Apollo's newly built sanctuary near Phigaleia reached their destination, the frieze proved to be so much longer than its intended space that there had to be recourse to extensive mutilation, applied even to shoulders, legs and arms of the struggling figures, before the sculpture could be set; and even then-at least in my judgment of this most intricate problem--the slabs were not aligned in the sequence which the artist had originally designed for them.

If it be objected that all such errors apply only to rather external and mechanical miscalculations and misfortunes, and that, considered as works of art, the individual statues none the less display the ideality and perfection of the great Greek tradition, I can only ask for more careful inspection of the course of Greek sculpture as it is nowadays understood. Here there is no static ideality of perfection in the accepted sense, for this involves the immutability of the abstract form, and that which is perfect (as Plato taught) is not subject to change; whereas, in Greek sculpture everything changes and nothing abides, whether in technical procedure or in artistic taste, in ambitions or abilities. If Polycleitus is Greek perfection, then Praxiteles and Lysippus belong to the decadence. The Victory of Samothrace, the Aphrodite of Melos, the Belvedere Torso make the attainments of Pheidias and Calamis and Myron appear undeveloped, struggling, immature. "No one bathes twice in the same river," said Herakleitos; yet the river abides. But the aphorism will not fit the stream of artistic effort and production, for here even the stream itself is constantly changing its behaviour and appearance. To select a single phase or period, to insist that by the classical perfection we mean (let us say) only the later fifth century before Christ, is arbitrary, disputable, too manifestly partial. The flowering of the various arts does not synchronize to make a common period of perfection. Pindar and Aeschylus were not contemporaries of Polycleitus and Skopas, nor were these in turn still alive when painting reached its prime.

It is not without importance for our argument to observe that the aftercomers, the epigonio, looking back on the Greek splendour and admiring it as the golden age of civilization, have not been unanimous on the phase or period of Greek culture which should most merit their approbation. Thus, to confine the topic to Greek sculpture, the taste of Augustan Rome singled out the fifth century B.c. and the severe athletic tradition of Polycleitus and his immediate predecessors as displaying the ideal of classic perfection, so antithetic to the advanced realism of the contemporary tradition. A little later, in the time of Nero, preference seems to have veered towards the fourth century and to have sought in Skopas and Praxiteles the truest norm of sculptural beauty.

Still later, in the time of Hadrian, there seems to have developed a very general liking for the archaic of the late sixth century and the formal art of the late fifth century B.c.; but in each case with a marked leaning toward its florid forms and the affected elegances in which both these periods culminated. In more modern times, Lessing saw the acme of sculptural achievement in the Laocoon, a work of the very close of the Greek creative period. Winckelmann and Goethe found the purest manifestation of the Greek spirit in Roman copies of Greek divinities from the fifth century B.c. The late nineteenth century despised the Apollo Belvedere, previously so greatly admired, and exaggeratedly commended the simply posed nude youths and elaborately draped maidens of the last of the sixth century B.c. To-day the taste of students and connoisseurs has passed behind the archaic to the primitive, and thought to find in the geometric phase of earliest Greek art the essential Hellenic striving for clarity and essential form, the Greek genius for narrative simplification in its starkest and hence most powerful aspect. So great a variety of taste can only suggest that Greek sculpture was not the immutably serene achievement of the European neo-classic tradition, but a shifting struggle against recalcitrant materials, a driving forward toward 
new objectives with all the consequent diversions of convention and revolt which mark art for a living process persisting only through ceaseless unrest and strife.

Under the scrutiny of archæology, the classic world thus disintegrates. It relinquishes its immutability, its aloofness, its calm, in short its classic quality. Just as the honest historian must find beneath the great men and great deeds of the past the same ill-willed unstable human nature, the same greed and cruelty and stupidity which stalk abroad through all our own lands and times, so the archæologist, peering close, penetrates the shimmering iridescent veil of the classic illusion in ancient life and art. Instead of a radiant and superhuman cloud-built quiet he finds a noisy flux and quarrelling, the failure and falsity which beset all human activity. Any true vision of ancient life must comprise innumerable glimpses of violent action and pitiless mutability, striving and mistake, disagreement, ill-luck, and ever-recurrent determination to succeed. The classical view of the classical world errs through just this absence of error and failure and conflict. Its very assumption of ideality and perfection marks it out as unliving and therefore as unreal.

We need not labour the point that the political, social, and moral background of the most ideally aloof of all artistic periods, the middle decade of the fifth century B.c., was one of bloodshed and disillusionment. Yet I cannot adequately make my point without some more specific reference to these divinely civilized Greeks as they saw and reported themselves for the benefit of posterity. The island of Melos hoped that it could remain neutral during the war between the two leading powers of the Greek world. But the Athenians came to it with the dishearteningly realistic observation that "as things are in this world of ours, Right exists only among powers of equal strength, whereas the strong do whatever they are able and the weak suffer what they must". Replied the Melians, "But all the other neutrals, when they see our plight, will side against you for fear that some day or other you will overrun them also". Nevertheless, and for no better pretext than that it was not convenient for them to have a neutral State in their immediate strategic neighbourhood, the Athenians attacked Melos; and when the inhabitants finally surrendered and threw themselves on their mercy, they put to death all the grown men, sold the women and children for slaves, and settled their own countrymen in the depopulated island. This was in the year 416 B.c., while Sophocles was still composing his ethically lofty dramas for the Attic stage, while Socrates was teaching moral philosophy to the youth of Athens, and the pupils of Pheidias had just finished carving the exquisite reliefs of the Nik Temple parapet.

Those were the times of which Thucydides wrote despairingly when he saw how a great war could destroy all the traditional tenets of civilized behaviour. As revolution spread from State to State, he noted the ever-increasing treachery of human relations, the atrocity of their mutual reprisals. Under stress of such forces, "words lost their normal meanings," he explained; "honour in action was despised and finally relinquished; society became divided into factions wherein no man any longer trusted his fellows . . . there was neither promise kept nor oath respected . . . in men's hopelessness for any enduring order of things, mere desire of self-preservation replaced all confidence and sense of security. . . Human nature, instinctively rebellious against law and order"-(I am still quoting Thucydides)-“"now shaking itself free, revealed itself ungovernable in its passions, without respect for justice, the foe of all authority. .. . The entire Hellenic world was drawn into the struggle . . . and the sufferings which resulted were as numerous as they were terrible, being even such as have occurred before and will occur again, so long as human nature remains what it is".

"So long as human nature remains what it is." This single phrase from Thucydides should be enough to shatter into a thousand splinters the silver mirror, the sunlit crystal, of the classical illusion.

Whence then came this persistent modern misrepresentation of the Greek genius? What inherent quality has thus caused Greek (and in so far as it is under Hellenic tutelage has included Latin) to serve as the outstanding example of the classic spirit? So far as the term itself goes, the word 'classic' means only highest grade. But this very usage implies a certain standard or norm or scale of perfection, which sets the classic thing apart, hors concours, among the jury rather than among the petitioners and general public, aloof, unattainable, Olympian. If only we could be content to claim that Greek and Roman literature rank high among the best of the world's literatures, that Greek sculpture may be merely its finest sculpture, Greek architecture deserves place with its noblest architecture, there would be little damage done to ourselves or to the Greek tradition; but we have made a special caste of these Hellenes and turned them into untouchables, at the top rather than at the bottom of our social order, isolating them from all other literature and art, and by this very segregation conferring upon them a bloodless and lifeless unreality. For in the final analysis the flawless is inhuman, the impec. cable is hateful, and classical perfection is a bore. 